\title{
Pengaruh Credit Risk Management Pada Financial Performance Bank Konvensional Yang Terdaftar di BEI
}

\author{
Ervina $^{1,}$, , Vivi Nur Fatimah ${ }^{2}$, dan Henny Setyo Lestari ${ }^{3}$ \\ ${ }^{1,2,3}$ Faculty of Economics and business, Trisakti University jakarta \\ Email address: \\ vievie26@yahoo.com,fififatimah25@gmail.com,henny_setyo_lestari@trisakti.ac.id
}

\begin{abstract}
The purpose of this study is to analyze the impact of credit risk management on the financial performance of Indonesian conventional banks in 2016-2020. The sample in this study was 32 conventional banks from 160 observations using purposive sampling technique and secondary data. The dependent variable in this paper is measured by profitability using the return on assets proxy while credit risk management as an independent variable. From the research results, LDR and NPLR have no effect on financial performance. CAR has a positive influence on financial performance so that bank managers are expected to be able to maintain their capital adequacy ratio in accordance with the provisions set by Bank Indonesia to maintain their financial performance because a high capital adequacy ratio is considered safe and tends to meet its financial obligations, while $C I R$ and LDR negative effect on financial performance. By increasing the ratio of costs to income indicates a low level of efficiency in banking operational costs, and low liquid assets will increase cash reserves to reduce liquidity risk. Investors can invest their funds in banks that have a high capital adequacy ratio, cost of income ratio and liquidity ratio to avoid financial risk.
\end{abstract}

Keywords: financial performance, credit risk management.

\begin{abstract}
Abstrak: Tujuan penelitian untuk menganalisis dampak manajemen risiko kredit terhadap kinerja keuangan perbankan konvensional Indonesia tahun 2016-2020. Sampel dalam penelitian ini adalah 32 bank konvensional dari 160 pengamatan dengan menggunakan teknik purposive sampling dan data sekunder. Variabel dependen dalam tulisan ini diukur dengan profitabilitas dengan menggunakan proksi return on assets sedangkan manajemen risiko kredit sebagai variabel independen. Dari hasil penelitian, LDR dan NPLR tidak berpengaruh terhadap kinerja keuangan. CAR memiliki pengaruh positif terhadap kinerja keuangan sehingga manajer perbankan diharapkan untuk dapat menjaga rasio kecukupan modalnya sesuai dengan ketentuan yang telah ditetapkan oleh Bank Indonesia untuk mempertahankan kinerja keuangannya karena dengan rasio kecukupan modal yang tinggi dianggap aman dan cenderung dapat memenuhi kewajiban keuangannya, sedangkan CIR dan LDR berpengaruh negatif terhadap kinerja keuangan. Dengan meningkatkan rasio biaya terhadap pendapatan menunjukkan rendahnya tingkat efisiensi dalam biaya operasional perbankan, dan asset likuid yang rendah akan meningkatkan cadangan kasnya untuk mengurangi risiko likuiditas. Investor dapat menginvestasikan dananya pada bank yang memiliki rasio kecukupan modal, rasio biaya pendapatan dan rasio likuiditas yang tinggi agar terhindar dari risiko keuangan.
\end{abstract}

Kata kunci: kinerja keuangan, manajemen risiko kredit. 


\section{PENDAHULUAN}

Perbankan dalam Undang Undang Nomor 10 Tahun 1998 dinyatakan bahwa semua hal yang berkaitan dengan kelembagaan, kegiatan usaha, serta cara dan proses dalam menjalankan kegiatan usahanya. Suatu badan usaha yang menyimpan dana masyarakat dan dan menyalurkan pinjaman kepada masyarakat yang membutuhkan dana untuk dalam bentuk pinjaman atau hal lainnya yang berhubungan dengan uang agar dapat meningkatkan kebutuhan hidup masyarakat disebut dengan bank. (Prasanjaya dan Ramantha, 2013) menyatakan bank memiliki posisi penting dalam kehidupan masyarakat dan sektor perbankan dapat memberikan pengaruh yang besar bagi sistem keuangan negara. Bank merupakan suatu lembaga perantara memiliki posisi seperti tempat penyimpanan uang, penyalur pembiayaan dari transaki yang telah diberikan, dan penyaluran kredit yang akhirnya mensejahterakan kehidupan bermasyarakat. (Asfaw dan Veni, 2015) Kinerja bank untuk dapat ditingkatkan diperlukan pengelolaan manajemen risiko kredit demi kelangsungan usaha bank tersebut. Manajemen risiko kredit yang efektif dalam praktiknya merupakan hal yang sangat penting dalam keselamatan, kesehatan dan profitabilitas bank.

Penelitian (Malla, 2018) menyatakan bahwa lebih dari 50\% dari total risiko dari bank maupun lembaga keuangan diseluruh dunia dikarenakan credit risk management yang buruk. (Alshatti, 2015) risiko kredit sebagai salah satu risiko yang paling banyak dihadapi oleh bank mengingat aktivitas pemberian kredit merupakan salah satu sumber pendapatan utama dalam bank, maka credit risk management yang baik akan mempengaruhi profitabilitas. (Al Zaidanin dan $\mathrm{Al}$ Zaidanin, 2021) lemahnya credit risk management dalam menganalisa kemampuan penerima credit untuk membayar kembali pinjamannya kepada bank dapat menempatkan financial performance bank bermasalah, sehingga pemangku kepentingan bank dan pemerintah terus bekerja keras mengembangkan kebijakan kepada para penerima pinjaman agar dapat meningkatkan kualitas kredit dan menurunkan masalah kredit macet. Karena dengan meningkatnya risiko kredit di perbankan maka semakin besar kemungkinan untuk terjadi krisis keuangan.

(Antwi, 2019) kinerja merupakan kemampuan suatu entitas untuk memperoleh dan mengelola sumber daya langkanya dengan beberapa cara untuk menemukan keunggulan kempetitif, kinerja secara umum dibagi atas kinerja keuangan atau ekonomi dan kinerja inovatif. financial performance merupakan proses menentukan karakteristik keuangan perusahaan dari hasil akuntansi dan menganalisa indicator kinerja perusahaan untuk kepentingan pemangku kepentingan. (Melwani, 2019) mengukur financial performance secara akurat adalah hal yang harus dilakukan oleh perusahaan tersebut dan telah menjadi perhatian bagi setiap pemangku kepentingan yang didapatkan dari rasio keuangan dalam laporan keuangan. Data yang diperoleh dari laporan keuangan tahunan dapat membantu para investor, manajemen dan kreditur dalam memberikan keputusan strategi perencanaan di masa depan. Analisis kinerja keuangan dapat menentukan posisi keuangan dalam untung atau rugi, biaya yang telah dikeluarkan dan tingkat persaingan industri dalam perusahaan. Sehingga kinerja keuangan perusahaan memegang kunci utama dalam memahami kesehatan keuangan suatu perusahaan.

Credit risk management merupakan fungsi dan aktivitas terkoordinasi untuk memantau dan mengelola risiko yang dihadapi organisasi dengan menggabungkan proses dan proses manajemen risiko utama dalam kaitannya dengan tujuan organisasi. Manajemen risiko tidak dikembangkan dan dirancang untuk sepenuhnya menghilangkan risiko, tetapi 
dimaksudkan untuk mengendalikan peluang dan risiko yang dapat menimbulkan risiko (Golitsis dan Fassas, 2019). Mengelola risiko kredit sangat penting bagi bank, karena merupakan bagian keseluruhan dari proses kredit. Memaksimalkan risiko bank dengan tingkat pengembalian risiko yang disesuaikan dengan mempertahankan eksposur risiko kredit dengan tujuan untuk melindungi bank dari dampak buruk risiko kredit (Poudel, 2012).

(Al Zaidanin and Al Zaidanin, 2021) dalam penelitiannya mengukur financial performance dengan menggunakan proksi return on assets. Faktor credit risk management yang akan mempengaruhi financial performance bank adalah capital adequacy ratio, non performing loans ratio, cost to income ratio, liquidity ratio, dan loans to deposit ratio. (Antwi, 2019) sudah tidak perlu diperdebatkan lagi bahwa bank memiliki peran penting dalam perkembangan suatu perekonomian suatu negara karena bank memainkan intermediasi keuangan utama dari unit yang surplus kepada yang deficit. Tidak dapat dipungkiri juga bahwa bank juga memerlukan modal seperti perusahaan lainnya bahkan modal lebih besar, modal sangat integral dalam bisnis perbankan sehingga banyak regulator diseluruh dunia sangat memberikan perhatian khusus pada masalah capital adequacy ratio selama beberapa dekade dan menjadi lebih sering setelah krisis ekonomi 2008.

Rasio yang digunakan untuk mengukur jumlah ekuitas dan cadangan lainnya yang dimiliki bank terhadap asset berisikonya adalah rasio kecukupan modal (capital adequacy ratio-CAR). Tujuan cadangan ini adalah untuk melindungi dana deposan dari risiko kredit atau dari kerugian lain yang tidak terduga (Million et al., 2015). CAR dianggap sebagai salah satu indikator dalam sektor perbankan yang digunakan oleh pemberi wewenang dalam menilai financial performance perbankan, bank yang kinerjanya baik memiliki kecukupan modal untuk menghadapi kerugian dengan menjaga kepercayaan pemangku kepentingan dan menjaga stabilitas sistem perbankan suatu perekonomian (aspal kumar dan Nazneen 2014). Menurut Bank Indonesia Nomor 15/12/PBI/2013 Tentang Kewajiban Penyediaan Modal Minimum Bank Umum telah menjelaskan penetapan CAR sebagai berikut: (1) $8 \%$ (delapan persen) dari asset tertimbang menurut risiko (ATMR) untuk bank dengan profil risiko peringkat 1 (satu). (2) 9\% (Sembilan persen) sampai kurang dari 10\% (sepuluh persen) dari ATMR untuk bank dengan profil risiko peringkat 2 (dua). (3) 10\% (sepuluh persen) sampai kurang dari $11 \%$ (sebelas persen) dari ATMR untuk bank dengan profil risiko peringkat 3 (tiga). (4) 11\% (sebelas persen) sampai kurang dari 14\% (empat belas persen) dari ATMR untuk bank dengan profil risiko peringkat 4 (empat) atau peringkat 5 (lima)

Jika bank tidak menyediakan modal minimum sebesar $8 \%$ seperti yang telah ditentukan pemerintah maka bank tersebut akan mengalami risiko modal. Oleh karena itu dalam memberikan pinjaman termasuk dalam kegiatan usaha yang beresiko memungkinkan pinjaman yang diberikan tidak terbayarkan sehingga akan mengalami kerugian keuangan akibat kredit macet. Tingginya capital adequacy ratio akan meningkatkan skala investasi yang menguntungkan sedangkan jika capital adequacy ratio rendah memungkinkan bank akan mempunyai skala investasi yang rendah (Afriyie dan Akotey 2011). Regulator melihat kecukupan modal sebagai relevansi untuk mempengaruhi kelangsungan hidup dan tingkat prifitabilitasnya sehingga bank di Ghana berusaha untuk meningkatkan persyaratan modal minimumnya yang telah ditetapkan (Antwi, 2019).

Non performing loans ratio (NPLR) yang dapat diketahui dari laporan keuangan dengan cara membandingkan total kredit yang bermasalah dengan total keseluruhan kredit. Menurut penelitian (Saputra dan Budiasih, 2016) dan (Anggreni dan Suardhika, 2014) 
menunjukkan tingginya NPLR akan menurunkan profitabilitas yang disebabkan perbankan akan menanggung risiko kredit yang mengakibatkan profitabilitas menurun. NPRL merupakan pengukuran yang penting dari kualitas asset dan struktur validitas portofolio kredit, di sisi dari efisisensi manajemen resiko kredit bank. NPLR yang tinggi merupakan petunjuk untuk manajemen dan pengawas bank menunjukan bahwa bank memiliki kualitas asset yang lemah dan berisiko tinggi (Al Zaidanin dan Al Zaidanin 2021). Semakin kecil NPLR yang diperoleh oleh bank maka akan semakin kecil risko yang di tanggung pihak bank, namun dalam kondisi NPLR bank tersebut tinggi maka akan memperbesar biaya pencadangan aktiva produktifnya yang dapat menyebabkan bank tersebut akan mengalami kebangkrutan maka standar yang ditetapkan oleh Bank Indonesia adalah kurang dari 5\% (Hidayati, 2013)

Cost to income ratio (CIR) dapat dikatakan sebagai faktor efisiensi perbankan. Rasio yang digunakan dalam penelitian sektor keuangan untuk melihat efisiensi khususnya dalam perbankan. Semakin tinggi cost to income ratio menunjukan rendahnya tingkat efisiensi dalam operasional bank. Oleh karena itu bank yang kurang efisien dalam pembiayaannya akan menurunkan profitabilitas (Putra, 2015). Terdapat hubungan antara CIR dan profitabilitas dalam literatur. Dalam meninjau efisiensi operasionalnya CIR didefinisikan sebagai biaya operasional dibagi dengan pendapatan operasional uang digunakan sebagain benchmark suatu bank (Antwi, 2019).

Liquidity ratio (LR) dapat dikatakan sebagai rasio modal kerja untuk mengukur seberapa lancarnya keuangan suatu perusahaan untuk memenuhi kewajibannya dalam pembayaran hutang yang telah jatuh tempo. LR yang diukur dengan asset likuidnya dibagi total kewajiban, menunjukkan bahwa semakin likuid asset bank, semakin kecil tingkat kegagalan pembayaran hutang bank (Ruziqa, 2013). Kewajiban yang harus terpenuhi adalah hutang jangka pendek, maka rasio LR dapat digunakan untuk mengukur tingkat keamanan kreditur jangka pendek dan mengukur apakah operasi perusahaan tidak akan terganggu bila kewajiban jangka pendek ini segera ditagih (Sabijono et al., 2014). Sebagai entitas ekonomi, bank membutuhkan uang tunai dan aset likuid yang dapat dengan mudah dikonversi menjadi uang tunai dalam waktu singkat. Risiko likuiditas mengurangi kemampuan bank saat memenuhi kewajiban keuangannya pada saat jatuh tempo, Jika risiko ini tidak dikendalikan, bank akan kehilangan nasabah dan karenanya mengurangi simpanan. Jika simpanan berkurang, bank tidak akan memiliki dana yang cukup untuk investasi lain, yang secara signifikan akan mengurangi profitabilitas maka risiko likuiditas tinggi menyebabkan kebangkrutan (Ejoh et al., 2014).

Loans to deposit ratio (LDR) untuk mengetahui kecukupan kewajiban finansial jangka pendek untuk membayar kembali deposito milik deposan yang telah jatuh tempo dengan tepat waktu dan pemberian pinjaman pada kreditur tanpa terjadi penangguhan (Christiano et al., 2014). Jika bank mempunyai kesanggupan untuk pembayaran penarikan giro, tabungan, deposito berjangka, pinjaman bank yang segera jatuh tempo, memenuhi permintaan kredit tanpa penundaan dari kredit yang dibuat, bank tersebut di anggap likuid. Semakin tinggi LDR suatu bank maka semakin rendah likuiditas bank tersebut, karena kebutuhan dana untuk membiayai pinjaman meningkat, sebaliknya semakin rendah LDR menyebabkan semakin tinggi likuiditas bank yang bersangkutan (Amalia, 2014).

Penelitian sebelumnya yang dilakukan oleh (Annor dan Obeng, 2018) untuk mengukur profitabilitas menggunakan ROE dengan variabel-variabel yang mempengaruhi risiko kreditnya dengan NPL,CAR, loan loss provision ratio (LLPR), rasio pinjaman 
terhadap asset (loan to asset ratio) pada bank komersial di Ghana Stock Exchange menyimpulkan bahwa CAR memiliki hubungan positif terhadap profitabilitas bank, sedangkan NPL, LLPR dan LAR memiliki hubungan negatif terhadap profitabilitas bank. Sehingga bank diharapkan dapat lebih fokus dalam mengelola indikator-indikator dari risiko kredit untuk mengurangi eksposur terhadap risiko ini. Dan pada penelitian (Million et al., 2015) menemukan bahwa indikator dari credit risk management yaitu CAR, NPL dan LLPR berpengaruh terhadap profitabilitas bank di Ethiopia. Non-perfotming loans mempunyai pengaruh positif terhadap profitabilitas bank. Oleh sebab itu, manajer bank sangat disarankan untuk menerapkan credit risk management yang modern dan dapat mendifersikasi aktivitas pendapatan bank.

Penelitian sebelumnya yang dilakukan oleh (Iftikhar, 2016) mengukur financial performance menggunakan ROA dengan variabel-variabel yang mempengaruhi variabel independen NPLR, CAR dari penelitian di bank pakistan memiliki dampak signifikan dari credit risk management, disarankan bahwa sistem credit risk management yang ketat sangat penting bagi manajer dan mereka disarankan untuk menyebarkan aktivitas produktif bank masing-masing. Dan penelitian (Alshatti, 2015) tentang pengaruh credit risk management terhadap financial performance bank komersial Yordania yang diukur dengan ROA dengan variabel NPL, CAR, Credit interests/Credit facilities (CI/CF), FL/NF dan LR menyimpulkan bahwa indikator credit risk management berpengaruh signifikan terhadap financial performance bank komersial Yordania. Bank di Yordania untuk meningkatkan credit risk management mereka untuk mencapai lebih banyak keuntungan, bank juga harus menetapkan kebijakan credit risk management yang memadai dengan menerapkan estimasi kredit yang ketat sebelum pemberian pinjaman kepada nasabah, dan bank dalam merancang sistem credit risk management yang efektif, perlu menetapkan lingkungan risiko kredit yang sesuai.

\section{KAJIAN TEORI}

Bank Menurut Undang Undang Nomor 10 Tahun 1998 bank adalah badan usaha yang mengumpulkan dana dari masyarakat dalam bentuk simpanan dan menyalurkan kepada masyarakat dalam bentuk pinjaman atau bentuk lainnya untuk meningkatkan taraf hidup masyarakat. Dan jenis - jenis bank terbagi dalam beberapa kriteria, yaitu:

Menurut fungsi kegiatannya: (1) Bank Umum : merupakan bank yang menjalankan usahanya secara konvensional dan atau prinsip Syariah yang kegiatannya memberikan imbalan jasa dalam kegiatan pembayaran. (2) Bank Perkreditan Rakyat : merupakan bank yang menjalankan usahanya secara konvensional dan atau prinsip Syariah yang kegiatannya tidak memberikan imbalan jasa dalam kegiatan pembayaran.

Menurut kepemilikannya: (1) Bank Milik Negara : Merupakan bank yang sebagian besar modalnya berasal dari pihak pemerintah pusat. (2) Bank Swasta Nasional: Merupakan bank yang sebagian besar modalnya berasal dari pihak swasta nasional. (3) Bank Asing : Merupakan bank yang kantor pusatnya di luar negeri yang membuka cabangnya di Indonesia dan sebagian besar modalnya dari pihak asing. (4) Bank Campuran : Merupakan bank yang modalnya berasal dari percampuran pihak asing dan pihak swasta nasioanal. 
Menurut kegiatan devisanya: (1) Bank Devisa : Bank yang melakukan usahanya melalui transaksi ke luar negeri yang seluruh transaksinya menggunakan mata uang asing. (2) Bank Non Devisa : Bank yang belum memiliki izin bank devisa sehingga usaha transaksinya sebatas dalam negara.

Menurut kegiatan operasionalnya: (1) Bank Konvensional : Bank yang kegiatan usahanya menggunakan prinsip konvensional. (2) Bank Syariah : Bank yang menjalankan usahanya menggunakan prinsip Syariah.

Financial Performance. (Matar dan Eneizan, 2018) bahwa kinerja merupakan indikator untuk mengukur penggunaan sumber daya yang efektif serta efisien dalam suatu perusahaan yang terbagi atas kinerja keuangan dan non-keuangan. Financial performance merupakan pengukuran kesehatan keuangan perusahaan dan menunjukan kemampuan manajemen kepemimpinan eksekutif dalam menjalankan organisasinya. (Fahmi, 2012) financial preformance merupakan hasil analisi perusahaan dalam menggunakan keuangannya secara efisien dan efektif yang biasanya dapat dilihat pada laporan laba rugi yang dikeluarkan manajer keuangan pada waktu tertentu yang menghasilkan rasio-rasio keuangan untuk menganalisa naik dan turunnya kinerja keuangan perusahaan tersebut. Sehingga dapat menciptakan sumber daya yang optimal yang siap menghadapi perubahan lingkungan. (Chashmi dan Fadaee, 2016) laporan kinerja yang dilakukan terus menerus akan memberikan informasi documenter yang akurat dan berharga untuk para manajer perusahaan dalam membuat keputusan untuk mempromosikan dan meningkatkan aktivitas perusahaan, pengukuran financial performance dapat didasari dengan menilai harga saham, risiko saham, kompenasasi eksekutif dan keputusan terkait investasi. Syarat untuk dapat terus bertahan dalam aktivitas perusahaan adalah ketepatan dan efisiensi sehingga kumpulan laporan aktivitas memiliki dampak yang kuat terhadap financial performance perusahaan. (Wanjohi dan Baimwera, 2016) financial performance merupakan kemampuan suatu perusahaan untuk menghasilkan sumber daya yang baru dari operasionalnya sehari-hari selama periode tertentu yang kinerjanya dapat diukur dengan laba bersih dan kas dari operasinya.

Return On Assets. (Asnawi et al., 2018) pengembalian aset (ROA) merupakan rasio kemampuan bank dalam memperoleh keuntungan dalam penggunaan asset yang dimilikinya. (Million et al., 2015) ROA dapat juga untuk mengukur efisiensi sumber daya langkanya dalam manajemen perbankan untuk mendapatkan keuntungan, semakin banyak pengembalian asetnya semakin baik efisiensi manajemen bank yang baik untuk bank tersebut. (Widati, 2016) tingkat profitabilitas ini dapat diukur dengan menggunakan rasio return on asset (ROA) karena ROA lebih memfokuskan pada kemampuan perusahaan secara keseluruhan, semakin besar ROA menunjukan kinerja perusahaan semakin baik, karena tingkat pengembalian (return) semakin besar. ROA juga dapat digunakan sebagai dasar evaluasi kinerja perbankan tahun yang telah dilalui atau pengambilan kebijakan untuk tahun yang akan dating, semakin tinggi ROA akan meningkatan profitabilitas bank tersebut dan sebaliknya jika ROA semakin rendah akan menurunkan profitabilitas bank.

Credit Risk Management. Menurut (Kalui, 2015) credit risk management merupakan sistem, kontrol, dan prosedur yang ditetapkan oleh perusahaan yang diharapkan dapat 
memastikan efisiensi dalam penagihan pembayaran dari pelanggan dan sehingga mengurangi kemungkinan gagal bayar. (Mozib Lalon, 2015) credit risk management terdiri dari mengidentifikasi, mengukur, mengurangi, memantau dan mengendalikan semua posisi risiko kredit. (Setiyawati dan Hartini, 2019) credit risk management sangat penting dalam perbankan untuk dapat bertahan dan berkembang, sehingga credit risk management dalam suatu bank harus memiliki pengetahuan secara luas tentang setiap latar belakang portofolio individu maupun campuran, industry dan konsentrasi geografis kredit, dan karakteristik aggregat lainnya. (Desda dan Yurasti, 2019) Bank perlu melaksanakan Proses Manajemen Risiko yang baik dalam pemberian kredit kepada masyarakat. Proses manajemen yang baik berfungsi untuk membatasi atau mencegah terjadinya kredit bermasalah. Pengendalian kredit bermasalah dipergunakan supaya tidak merugikan pihak bank dikarenakan pendapatn tertinggi bank didapatkan dari penyaluran kredit. (Nwude dan Okeke, 2018) Semua kegiatan usaha yang memiliki risiko harus memnutuhkan manajemen risiko, tak terlepas pada perbankan. Credit risk management yang efektif akan menurunkan efek risiko yang negative dan dapat memaksimalkan manfaat positif yang telah diberikan.

Capital Adequacy Ratio. (Pinasti and Mustikawati, 2018) CAR adalah besarnya permodalan suatu bank yang mampu digunakan dalam kegiatan operasionalnya secara baik dan benar. (Antwi, 2019) Kecukupan modal dianggap variable yang penting dalam bisnis perbankan, modal tersebut dapat digunakan untuk kebutuhan sehari-hari, ekspansi, bisnis berkelanjutan dan melindungi dana deposan. Modal juga berfungsi sebagai pendorong kepercayaan kepada nasabah, masyarakat umum dan pemerintah dengan keyakinan pada kemampuan keuangan bank yang berkelanjutan. (Aspal dan nazneen, 2014) CAR merupakan rasio kecukupan modal yang mengukur tentang kesehatan keuangan bank dan dibutuhkan oleh bank untuk menghindari resiko keuangan. Sebuah bank dengan kecukupan modal (CAR) yang tinggi memiliki keuntungan yang lebih besar dalam mengelola operasioanlnya untuk menghadapi risiko keuangan pada suatu waktu yang tidak diduga, sehingga menurut penelitinanya bahwa CAR berpengaruh positif terhadap financial performance (Irawati et al., 2019; (Teshome et al., 2014); (Annor and Obeng, 2018); (Saputra and Budiasih, 2016) dan (Rajkumar dan Hanitha, 2015) menyimpulkan bahwa kecukupan modal (CAR) memiliki hubungan negatif yang kuat kepada financial performance bank. Ini mungkin tidak berdampak serius pada financial performance bank komersial UEA, tetapi jika rasio ini terus meningkat, ada potensi berdampak negatif atau positif pada financial performance bank komersial dalam jangka panjang tergantung pada kualitas dan penggunaan aset dan berapa banyak bank yang dapat mengelola risiko kreditnya. Penelitian yang berbeda pada (Al Zaidanin dan Al Zaidanin, 2021) yang meneliti bahwa (CAR) kecukupan modal tidak berpengaruh secara signifikan kepada financial performance.

H1: Kecukupan modal (capital adequancy ratio) memiliki pengaruh terhadap financial performance.

Non-performing Loans Ratio (kredit macet). (Kauko, 2012) kredit macet (NPLR) merupakan pembayaran kredit nasabah yang terlambat. (Million et al., 2015) NPLR yang mengukur sejauh mana risiko gagal yang akan dihadapi bank. Jika rasio ini meningkat, ini akan memberikan signal kepada manajemen bank karena menunjukkan probabilitas yang 
tinggi tanpa adanya perlindungan terhadap asset utama bank. Dengan meningkatnya NPLR akan mengakibatkan penurunan ROA dikarenakan rasio NPL yang tinggi akan menyebabkan cadangan tambahan untuk melindungi risikonya yang akhirnya akan menurunkan profitabilitas, sehingga NPLR memiliki hubungan yang negatif terhadap financial performance (Ruziqa, 2013; Teshome et al., 2014; Annor dan Obeng, 2018; Irawati et al., 2019). Hal ini didukung oleh (Al Zaidanin and Al Zaidanin, 2021) pada penelitian bank umum UEA secara statistik memiliki berpengaruh negatif yang kuat terhadap ROA. Hal ini mengartikan bahwa NPLR yang tinggi maka profitabilitas bank umum di UEA akan semakin kecil Tetapi kebijakan keuangan yang sehat dan menajemen pengelolaan risiko kredit yang baik akan meningkatkan financial performance bank tersebut.

H2: Non performing loans ratio (NPLR) berpengaruh terhadap financial performance.

Cost Income Ratio. (Chalise, 2017) CIR adalah rasio keuangan yang sangat penting dalam menilai bank dengan menunjukkan biaya perusahaan dalam hubungannya dengan pendapatan. Untuk mendapatkan rasio ini, membagi biaya operasional (administrasi dan biaya tetap, seperti gaji dan biaya properti, tetapi bukan piutang tak tertagih yang telah dihapuskan) oleh pendapatan operasional. (Antwi, 2019) CIR memiliki pengaruh negatif yang kuat secara statistik terhadap return on asset maupun return on equity bank di Ghana. Hasil penelitian yang sama pada (Rajkumar dan Hanitha, 2015) pada bank umum di Srilanka dan (Teshome et al., 2014) yang meneliti financial performance bank umum Ethiopia selama tahun 2007-2016 dan menyimpulkan bahwa CIR memiliki pengaruh signifikan negative kepada return on asset . Hasil empiris ini sejalan dengan (Al Zaidanin dan $\mathrm{Al}$ Zaidanin, 2021) yang menyimpulkan semakin meningkatnya CIR maka semakin menurun profitabilitas bank komersial UEA yang artinya CIR berpengaruh negatif terhadap ROA. sebab itu penting sekali bagi bank komersial UEA dapat mengelola kegiatan operasional dan utama mereka sedemikian rupa sehingga mereka dapat menjaga CIR serendah mungkin dengan meningkatan manajemen biaya operasi yang efisiens untuk meningkatkan profitabilitas mereka.

H3: Cost to income ratio (CIR) berpengaruh terhadap financial performance.

Liquidity Ratio. (Harsana et al., 2018) Liquidity ratio merupakan rasio keuangan yang biasa digunakan untuk mengukur kapabilitas suatu perusahaan dalam pembayaran hutang jangka pendeknya. (Herry, 2016) Liquidity ratio merupakan rasio yang menunjukan kesanggupan organisasi dalam menyelesaikan kewajiban jangka pendeknya yang telah jatuh tempo. (Ruziqa, 2013) Bank dengan asset likuid yang tinggi, memiliki kondisi kegagalan yang rendah Tetapi bank yang asset likuidnya rendah harus dapat meningkatakan cadangan kasnya yang mungkin didapatkan dari pendanaan eksternal sehingga mengurangi risiko likuiditas pada bank. Penelitiannya menyimpulkan liquidity ratio (LR) memiliki pengaruh kuat yang negatif terhadap financial performance. Menurut penelitian (Teshome et al., 2014) menyimpulkan LR memiliki pengaruh positif signifikan terhadap ROA, stabilitas bank merupakan fungsi dari kombinasi credit risk management dan likuiditas. Bank yang efektif memiliki pengendalian sistem internal yang baik untuk mengawasi mekanisme pengendalian risiko yang digunakannya (Ejoh et al., 2014) Hasil penelitian (Al Zaidanin 
dan Al Zaidanin, 2021) menyimpulkan liquidity ratio tidak berpengaruh terhadap financial performace di bank komersial di the United Arab Emirates (UAE).

H4: Liquidity ratio (LR) berpengaruh terhadap financial performance.

Loan to Deposit Ratio. (Soegeng et al., 2018) rasio pinjaman terhadap deposito (LDR) digunakan untuk menilai likuiditas suatu perbankan, jika nilai LDR rendah maka tingkat likuiditas bank akan tinggi sehingga dapat menyebabkan kerugian pada bank. Sedangkan jika nilai LDR tinggi dan pemberian kredit juga tinggi maka akan menyebabkan bank mengalami kesulitan likuiditas. Dapat di simpulkan bahwa LDR memiliki pengaruh negatif yang kuat terhadap ROA, berdasarkn dengan Peraturan Bank Indonesia Nomor 18/14/PBI/2016 loan to deposit ratio ditetapkan antara 80\% hingga 92\% untuk melindungi bank dari kerugian, kebangkrutan maupun masalah likuiditas. (Widati et al., 2016) berpendapat bahwa loan to deposits ratio pengaruh negatif yang kuat terhadap return on asset artinya bahwa bank kurang optimal dalam menyalurkan kredit dengan memanfaatkan modalnya. Jika LDR terlalu rendah maka likuiditas bank akan semakin tinggi sehingga akan menimbulkan kerugian bagi bank. Jika LDR terlalu tinggi, maka penyaluran kredit menjadi lebih tinggi sehingga bank mengalami kesulitan likuiditas. terdapat penelitian lainnya yang menemukan bahwa bahwa $L D R$ memiliki pengaruh kuat yang positif terhadap ROA (Christiano et al., 2014). Penelitian yang berbeda dari (Al Zaidanin dan Al Zaidanin, 2021) yang meneliti pengaruh $L D R$, menemukan tidak terdapat pengaruh kepada financial performance.

H5: Loans to deposit ratio (LDR) berpengaruh terhadap financial performance.

Variabel Independen $\quad$ Variabel Dependen

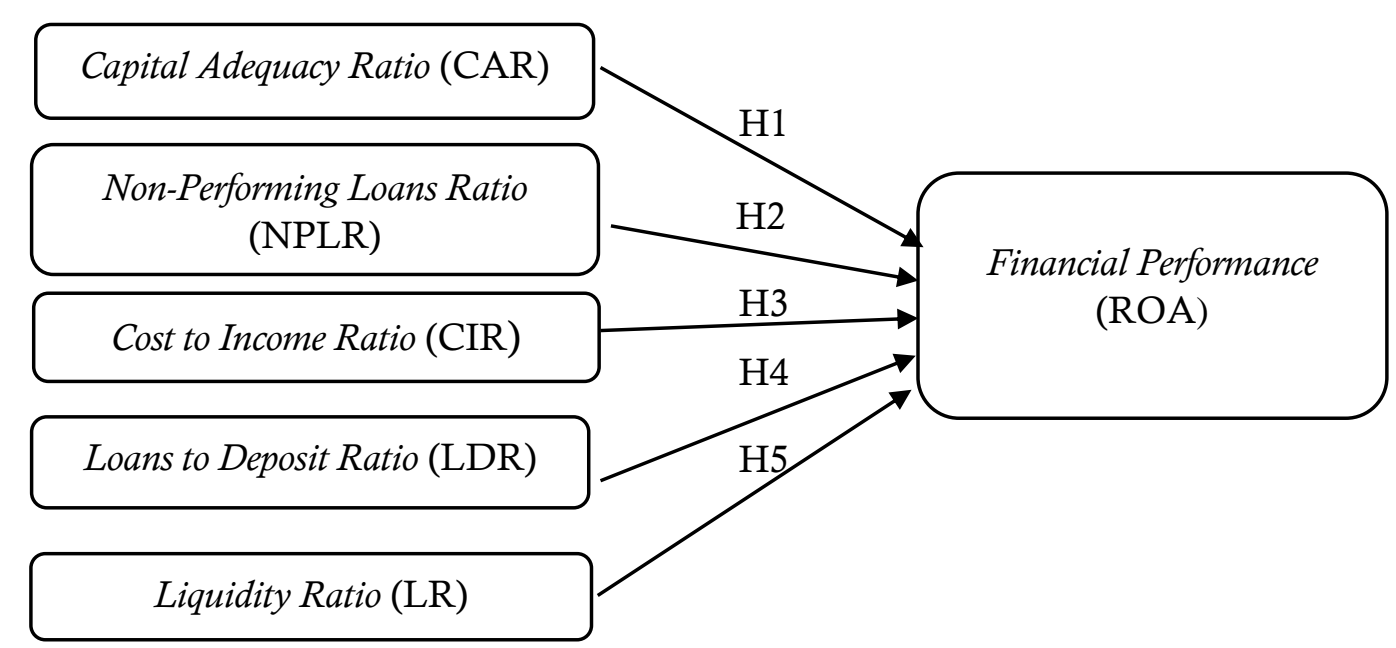

Gambar 1. Model Penelitian 


\section{METODOLOGI}

Penelitian ini bertujuan menguji hipotesis testing untuk mengetahui karakteristik variabelnya dimana varibel dependennya adalah financial performance, dan variable independennya adalah credit risk management menggunakan lima proksi varibel, yaitu capital adequacy ratio, non performing loans ratio, cost to income ratio, liquidity ratio, dan loans to deposit ratio. Metodenya menggunakan data panel regresi analisis. Objek yang dipakai sebanyak 32 bank konvensional Indonesia dengan data sekunder keuangan tahunan selama 5 tahun pada periode 2016 hingga 2020 yang didapatkan melalui website www.idx.co.id. Teknik purpose sampling dalam penarikan sampel. Alat atau software yang digunakan untuk mengelola data adalah E-views 10.0. Metode ini merupakan metode penarikan sampel yang populasinya mengacu pada perusahaan yang memenuhi beberapa kriteria tertentu.

Tabel 1. Penarikan Sampel Perusahan

\begin{tabular}{lc}
\hline Keterangan & Jumlah perusahan \\
\hline Sektor industri perbankan yang terdaftar di Bursa Efek Indonesia (BEI) pada & 43 \\
tahun 2020 & 11 \\
Bank yang tidak termasuk dalam penelitian ini & 32 \\
Jumlah sampel yang memiliki data variabel yang dibutuhkan dalam penelitian & 160 \\
ini 2016-2020 & \\
Total data observasi 32 x 5 tahun &
\end{tabular}

Sumber: Hasil pengolahan peneliti (2021)

Tabel 2. Pengukuran Operasional Variabel

\begin{tabular}{lc}
\hline \multicolumn{1}{c}{ Variabel } & Proksi \\
\hline Dependen & $R O A=\frac{\text { Nett } \text { income }}{\text { Total Assets }}$ \\
\hline Retur on Asset & $C A R=\frac{\text { Total Capital }}{\text { Total Assets }}$ \\
\hline Independen & $N P L R=\frac{\text { Non }- \text { performing Loans }}{\text { Total Loans \& Advances }}$ \\
\hline Capital Adequacy Ratio & $C I R=\frac{\text { Total Operating Cost }}{\text { Total Operating Income }}$ \\
\hline Non Performing Loans Ratio & $L R=\frac{\text { Liquid Assets }}{\text { Total Liabilities }}$ \\
\hline Cost to Income Ratio & $L D R=\frac{\text { Total Loan \& Advance }}{\text { Total Deposits }}$ \\
\hline Liquidity Ratio &
\end{tabular}

Metode analisis data dengan mengunakan data regresi panel karena menggunakan cross sectional dan data time series yang dirumuskan sebagai berikut: 


$$
\mathrm{ROA}_{i t}=\alpha+\beta_{1} \mathrm{NPLR}_{\mathrm{it}}+\beta_{2} \mathrm{CAR}_{\mathrm{it}}+\beta_{3} \mathrm{CIR}_{\mathrm{it}}+\beta_{4} \mathrm{LR}_{\mathrm{it}}+\beta_{5} \mathrm{LDR}_{\mathrm{it}}+\varepsilon_{\mathrm{it}} .
$$

Di mana:

$$
\begin{aligned}
& \alpha \quad=\text { Konstanta } \\
& \text { ROA }=\text { Return on Assets i pada waktu }{ }_{\mathrm{t}} \\
& \text { NPLR }=\text { Non-Performing Loans Ratio } \text { i pada waktu }_{\mathrm{t}} \\
& \text { CAR = Capital Adequacy Ratio }{ }_{\text {i }} \text { pada waktu }{ }_{\mathrm{t}} \\
& \text { CIR = Cost to Income Ratio }{ }_{\text {i }} \text { pada waktu }{ }_{\mathrm{t}} \\
& \text { LR = Liquidity Ratio }{ }_{\mathrm{i}} \text { pada waktu } \mathrm{t}_{\mathrm{t}} \\
& \text { LDR = Loans-to-Deposit Ratio }{ }_{\text {i }} \text { pada }_{\text {waktu }}{ }_{\mathrm{t}} \\
& \varepsilon \quad=\text { Error }
\end{aligned}
$$

\section{HASIL PENELITIAN}

Statistik Deskriptif. Statistik deskriptif memberikan gambaran karakteristik dari variabel yang digunakan dalam penelitian serta ditinjau dari mean, median, maximum, minimum, standart deviasi, dan observation.

Tabel 3. Hasil Analisis Statistik Deskriptif

\begin{tabular}{lcccccc}
\hline & ROA & NPL & CAR & CIR & LR & LDR \\
\hline Mean & 1.066188 & 3.475438 & 24.18238 & 89.08475 & 0.358375 & 88.86800 \\
\hline Median & 1.485000 & 2.870000 & 21.37000 & 86.12500 & 0.280000 & 86.84000 \\
\hline Maximum & 4.000000 & 22.27000 & 125.6500 & 235.2000 & 2.670000 & 466.7800 \\
\hline Minimum & -11.15000 & 0.000000 & 9.010000 & 25.70000 & 0.110000 & 19.91000 \\
\hline Std. Dev. & 2.229635 & 2.597060 & 12.79771 & 26.33231 & 0.329528 & 35.76232 \\
\hline Observation & 160 & 160 & 160 & 160 & 160 & 160 \\
\hline Sumber: Hasl pengo
\end{tabular}

Sumber: Hasil pengolahan E-views (2021)

Pada tabel 3 diatas, menghasilkan nilai minimum terendah ada pada variabel nonperforming loans ratio, nilai maximum yang tertinggi pada variabel loan to deposite ratio, nilai mean tertinggi pada cost to income ratio, dan standart deviasi tertinggi pada loan to deposit ratio.

Metode regresi data panel yang digunakan adalah common effect, fixed effect, dan random effect tujuannya untuk mengetahui pengaruh variabel independen terhadap variable dependen. Terdapat dua tahap dalam dalam menemukan model yang tepat dan baik untuk diinterpretasikan yaitu Chow test dan Hausman test. Chow test digunakan dalam menguji kesesuain model antara metode common effect dan metode fix effect. Selanjutnya, Hausman test digunakan dalam menguji kesesuaian model dari metode fix effect dengan metode random effect. Hasil pengujian data panel dapat dilihat pada table 3 dan table 4:

Tabel 4. Hasil Uji Chow

\begin{tabular}{ccccc}
\hline Effects Test & Model & Prob. & Hyphothesis & Conclusion \\
\hline $\begin{array}{c}\text { Cross-Section Chi- } \\
\text { Square }\end{array}$ & Model 1 & 0.0000 & Ha Diterima & Fixed Effects Model \\
\hline
\end{tabular}

Sumber: Hasil pengolahan E-views (2021) 
Hasil table 3 diatas menghasilkan nilai dari Prob. Cross-Section Chi-Square model 1 dengan nilai $p$-value 0.0000 yang lebih kecil dari taraf signifikannya yaitu 0.05 , sehingga Ha Diterima. Disimpulkan bahwa model terbaik yang terpilih adalah Fixed Effects maka dilanjutkan dengan Hausman Test.

Tabel 5. Hasil Uji Hausman test

\begin{tabular}{ccccc}
\hline Effects Test & Model & Prob. & Hyphothesis & Conclusion \\
\hline Cross-Section Random & Model 1 & 0.0004 & Ha Diterima & Fixed Effects Model \\
\hline
\end{tabular}

Sumber: Hasil pengolahan E-views (2021)

Hasil table 5 menunjukkan bahwa hasil dari Prob. Cross-Section Random model 1 dengan nilai $p$-value 0.0004 lebih kecil dari taraf signifikannya yaitu 0.05 , sehingga Ha Diterima. Dapat disimpulkan bahwa Fixed Effects Model yang terpilih.

Tabel 6. Hasil uji Koefisiensi Determinasi

\begin{tabular}{ccc}
\hline Testing & Model & Value \\
\hline Adjusted R-Squared & Model 1 & 0.985992 \\
\hline
\end{tabular}

Sumber: Hasil pengolahan E-views (2021)

Hasil tabel 6 di atas, bahwa nilai Adjusted R-Squared pada model 1 sebesar 0.9859 atau $98.59 \%$. Menunjukkan bahwa seluruh variabel independen dapat menjelaskan variabel dependen sebesar $98.59 \%$, sisanya sebesar $1.41 \%$ dijelaskan oleh variabel lain di luar model

Tabel 7. Hasil uji f

\begin{tabular}{lllll}
\hline Dependen & F-statistic & Prob. & Hyphothesis & Conclusion \\
\hline ROA & 311.8766 & 0.0004 & Ha Diterima & Berpengaruh Signifikan \\
\hline
\end{tabular}

Sumber: Hasil pengolahan E-views (2021)

Hasil table 7, menunjukkan nilai dari Prob (F-Statistic) pada model diatas sebesar 0.0000 lebih kecil dari taraf signifikannya yaitu 0.05 sehingga Ha Diterima. Dapat disimpulkan bahwa secara serentak seluruh variabel independen berpengaruh signifikan terhadap variabel dependen.

Tabel 8. Hasil uji goodness of fit

\begin{tabular}{lcl}
\hline Dependen & $\boldsymbol{R}^{\mathbf{2}}$ & Adjusted $\boldsymbol{R}^{\mathbf{2}}$ \\
\hline ROA & 0.989164 & 0.985992
\end{tabular}

Sumber: Hasil pengolahan E-views (2021)

Berdasarkan hasil pada table 8, diperoleh nilai adjusted r-square sebesar 0.985992 . Hal ini berarti variabel independen mampu menjelaskan variasi dari return on asset (ROA) 
sebesar 98,5992\% dan sisanya 1,4008\% menjelaskan bahwa return on asset (ROA) dapat dipengaruhi oleh faktor lain yang tidak terdapat dalam model ini.

Tabel 9. Hasil uji t

\begin{tabular}{llll}
\hline Variabel Independen & \multicolumn{2}{c}{ Variabel Dependen: ROA } \\
\cline { 2 - 4 } & Coefficient & Prob. & Conclusion \\
\hline C & 9.304965 & 0.0000 & \\
CAR & 0.014004 & 0.5255 & Tidak Berpengaruh \\
NPLR & 0.005667 & 0.0011 & Berpengaruh Signifikan \\
CIR & -0.090561 & 0.0000 & Berpengaruh Signifikan \\
LR & -0.469410 & 0.0004 & Berpengaruh Signifikan \\
LDR & -0.002123 & 0.1764 & Tidak Berpengaruh \\
\hline
\end{tabular}

Sumber: Hasil pengolahan E-views (2021)

Tabel 10. Hasil Regresi Linear Berganda

\begin{tabular}{cllll}
\hline Variable & Coeff & Std. Er & t-Stat & Prob. \\
\hline C & 9.211877 & 0.263558 & 34.95201 & 0.0000 \\
\hline NPL? & 0.047996 & 0.026364 & 1.820534 & 0.0711 \\
\hline CAR? & 0.012156 & 0.009441 & 1.287581 & 0.2003 \\
\hline CIR? & -0.089567 & 0.002994 & -29.91733 & 0.0000 \\
\hline LR? & -1.043871 & 0.392888 & -2.656921 & 0.0089 \\
\hline LDR? & -0.002850 & 0.001799 & -1.584386 & 0.1157
\end{tabular}

Sumber: Hasil pengolahan E-views (2021)

Maka berdasarkan tabel 10 persamaan model regresi linear berganda adalah:

$\mathrm{ROA}_{\mathrm{it}}=9.304965+0.014004 \mathrm{NPLR}_{\mathrm{it}}+0.005667 \mathrm{CAR}_{\mathrm{it}}-0.090561 \mathrm{CIR}_{\mathrm{it}}-0.469410 \mathrm{LR}_{\mathrm{it}}-$ $0.002123 \mathrm{LDR}_{\text {it }}$

Di mana:

$\alpha \quad=$ Konstanta

ROA = Return on Assets

CAR = Capital Adequacy Ratio

NPLR = Non-Performing Loans Ratio

CIR = Cost to Income Ratio

LR = Liquidity Ratio

LDR = Loans-to-Deposit Ratio

$\varepsilon \quad=$ Error

Hasil perumusan model persamaan model regresi liner berganda, maka dapat disimpulkan: (1) Jika nilai pada variabel capital adequacy ratio, non-performing loans ratio, cost to income ratio, liquidity ratio, dan loans to deposit ratio sama dengan nol, maka return on assets sebesar 9.211877. (2) Jika nilai pada non-performing loans ratio naik satu satuan maka akan menaikkan return on assets sebesar 0.047996 satuan. Sebaliknya jika variabel non-performing loans ratio turun satu satuan maka return on assets akan turun sebesar 0.047996 satuan. Dengan asumsi capital adequacy ratio, cost to income ratio, 
liquidity ratio, dan loans to deposit ratio dianggap konstan. (3) Jika nilai pada capital adequacy ratio naik satu satuan maka akan menaikkan return on assets sebesar 0.047996 satuan. Sebaliknya jika variabel capital adequacy ratio turun satu satuan maka return on assets akan turun sebesar 0.047996 satuan. Dengan asumsi non-performing loans ratio, cost to income ratio, liquidity ratio, dan loans to deposit ratio dianggap konstan.(4) Jika nilai pada cost to income ratio naik satu satuan makaakan menurunkan return on assets sebesar 0.089567 satuan. Sebaliknya jika variabel cost to income ratio turun satu satuan maka return on assets akan naik sebesar 0.089567 satuan. Dengan asumsi capital adequacy ratio, nonperforming loans ratio, liquidity ratio, dan loans to deposit ratio dianggap konstan. (5) Jika nilai pada liquidity ratio naik satu satuan maka akan menurunkan return on assets sebesar 1.043871 satuan. Sebaliknya jika variabel liquidity ratio turun satu satuan maka return on assets akan naik sebesar 1.043871 satuan. Dengan asumsi capital adequacy ratio, nonperforming loans ratio, cost to income ratio, dan loans to deposit ratio dianggap konstan. (5) Jika nilai pada loans to deposit ratio naik satu satuan maka menurunkan return on assets sebesar 0.002850 satuan. Sebaliknya jika variabel loans to deposit ratio turun satu satuan maka return on assets akan naik sebesar 0.002850 satuan. Dengan asumsi capital adequacy ratio, non-performing loans ratio, cost to income ratio, dan liquidity ratio dianggap konstan.

\section{DISKUSI}

Tujuan penelitian ini untuk mengetahui pengaruh credit risk management pada finacial performance. Jumlah sampel penelitian diperoleh dari bank konvensional yang terdaftar di Bursa Efek Indonesia 2016-2020.

Hasil hipotesis pertama, CAR memiliki probabilitas 0.0011 lebih kecil dari taraf signifikan 0.05 yang menyimpulkan CAR pengaruh signifikan yang positif, dengan nilai koefisien regresi 0.005667. Penemuan ini sejalan dengan (Teshome et al., 2014; Isanzu dan Juliana, 2017).

Hasil hipotesis kedua, NPL memiliki probabilitas 0.5255 lebih besar dari taraf signifikan 0.05 yang menunjukkan tidak ada pengaruh dengan nilai koefisien regresi 0.014004. Penelitian ini juga didukung oleh (Andriyani dan Leon, 2021; Lukitasari dan Kartika, 2015; Septiani dan Lestari, 2016).

Hasil hipotesis ketiga, CIR memiliki probabilitas 0.0000 lebih kecil dari taraf signifikan 0.05 yang menunjukkan pengaruh signifikan yang negative dengan nilai koefisien regresi sebesar 0.090561. Penelitian ini juga didukung oleh (Chalise, 2017; Prasetyo, 2020; Antwi, 2019)

Hasil hipotesis keempat, LR memiliki probabilitas 0.0004 lebih kecil dari taraf signifikan 0.05 yang menunjukkan pengaruh signifikan yang negative dengan nilai koefisien regresi 0.469410. Penelitian ini didukung oleh (Kingu et al., 2018; Matar dan Eneizan, 2018).

Hasil hipotesis kelima, LDR memiliki probabilitas 0.1764 lebih besar dari taraf signifikan 0.05 yang menunjukkan bahwa tidak ada pengaruh dengan nilai koefisien regresi 0.002123. Penelitian ini juga didukung oleh (Prasetyo, 2020; Syamsiah et al., 2021). 


\section{KESIMPULAN}

Kesimpulan pada penelitian ini membuktikan bahwa non-performing loans ratio dan loan to deposit ratio tidak memiliki pengaruh terhadap financial performance bank (retur on asset). Capital adequacy ratio terdapat pengaruh positif signifikan terhadap retur on asset, sedangkan cost to income ratio dan liquidity ratio terdapat pengaruh negatif signifikan terhadap retur on asset. Analisis dari penelitian ini berguna bagi para investor dalam mempertimbangan pilihan bank konvensional untuk berinvestasi. Para investor perlu mengetahui aspek-aspek apa yang mempengaruhi profitabilitas bank, dan para investor juga dapat mengukur kecukupan modal pada bank tersebut, maka bank tersebut menunjukkan bahwa bank memiliki kinerja keuangan yang memadai sehingga aman untuk berinvestasi. Untuk manajer bank, pada saat meningkatkan kinerja bank, semestinya manajemen bank mengamati aspek-aspek yang mempengaruhi kinerja bank dan yang terbukti dalam naik dan turunnya keuntungan yang dicerminkan dari return on asset (ROA). Sebaiknya manajer bank untuk lebih berhati hati dalam menjaga modal yang dimilikinya dalam menyalurkan kredit kepada calon penerima kredit atau debitur agar bank bisa menimalisir risiko kredit. Bank juga dapat memberikan penawaran yang menarik bagi para nasabahnya, minat untuk menabung dan melakukan transaksi akan meningkat. Hutang adalah sebagai modal utama bank untuk mendorong pengembangan kegaiatannya agar bisa memenuhi kewajibannya, maka dapat meningkatkan laba bank dan keuntungan bagi para pemegang saham.

Penelitian ini juga memiliki keterbatasan, hanya dilakukan pada bank konvensional yang terdaftar pada BEI, masa penelitian hanya lima tahun dan hanya menggunakan lima variabel dalam penelitian sehingga penelitian ini dalam lingkup yang kecil. Saran dalam penelitian selanjuatnya dapat menambahkan bank Syariah dan menambahkan variabel bank size, loan loss provision, net income margin, dan return on equity.

\section{DAFTAR PUSTAKA}

Al Zaidanin, J. S., and Al Zaidanin, O. J. (2021). The impact of credit risk management on the financial performance of United Arab Emirates commercial banks. International Journal of Research in Business and Social Science (2147- 4478), 10(3), 303-319. https://doi.org/10.20525/ijrbs.v10i3.1102.

Alshatti, A. sulieman. (2015). The effect of credit risk management on financial performance of the Jordanian commercial bank. Investment Management and Financial Innovations, 12(1), 338-345.

Andriyani, K. A., dan Leon, F. M. (2021). Dampak Manajemen Risiko Pada Kinerja Keuangan Bank Umum Konvensional Di Indonesia. Jurnal Magister Akuntansi Trisakti, 8(1), 29. https://doi.org/10.25105/jmat.v8i1.8148.

Anggreni, M. R., dan Suardhika, I. M. S. (2014). Fakultas Ekonomi dan Bisnis Universitas Udayana , Bali , Indonesia. E-Jurnal Akuntansi Universitas Udayana. 9.1 (2014), 1(ISSN: 2302-8556), 27-37.

Annor, E., and Obeng, F. (2018). Impact of Credit Risk Management on the Profitability of Selected Commercial Banks Listed on the Ghana Stock Exchange. Journal of Economics, Management and Trade, 20(2), 1-10. https://doi.org/10.9734/jemt/2017/36881.

Antwi, F. (2019). Capital Adequacy, Cost Income Ratio and Performance of Banks in 
Ghana. International Journal of Academic Research in Business and Social Sciences, 9(10), 168-184. https://doi.org/10.6007/ijarbss/v9-i10/6471.

Asfaw, A. H., and Veni, P. P. (2015). Empharical Study on Credit Risk Management Practice of Ethiopian Commercial Banks. Reseach Journal of Finance and Accounitng, 6(3), 134-147.

Asnawi, W. A., Rate, P. Van, Sam, U., dan Manado, R. (2018). Pengaruh Kinerja Keuangan Bank Terhadap Return on Asset (Roa) Studi Pada Bank Umum Devisa Buku 4. Jurnal EMBA: Jurnal Riset Ekonomi, Manajemen, Bisnis Dan Akuntansi, 6(4), 2898-2907. https://doi.org/10.35794/emba.v6i4.21198.

aspal kumar, P., and Nazneen, A. (2014). An Empirical Analysis of Capital Adequacy in the Indian Private Sector Banks. American Journal of Research Communication, 2(11), 28-42. www.usa-journals.com.

Chalise, S. (2017). The Impact of Capital Adequacy and Bank Operating Efficiency on Financial Performance of Nepalese Commercial Banks. SSRN Electronic Journal, 6(7), 78-83. https://doi.org/10.2139/ssrn.3044068.

Chashmi, N., and Fadaee, M. (2016). Impact of Financial Performance and Growth Opportunities on Success or Failure of Companies: Evidence from Tehran Stock Exchange. Journal of Accounting \& Marketing, 5(2), 2-5. https://doi.org/10.4172/2168-9601.1000166.

Christiano, M., Tommy, P., dan Saerang, I. (2014). Analisis Terhadap Rasio-rasio Keuangan Untuk Mengukur Profitabilitas Pada Bank-bank Swasta Yang Go Public Di Bursa Efek Indonesia. Jurnal Riset Ekonomi, Manajemen, Bisnis Dan Akuntansi, 2(4), 817-830. https://doi.org/10.35794/emba.v2i4.6490.

Desda, M. M., dan Yurasti, Y. (2019). Analisis Penerapan Manajemen Risiko Kredit Dalam Meminimalisir Kredit Bermasalah Pada PT. BPR Swadaya Anak Nagari Bandarejo Simpang Empat Periode 2013-2018. Mbia, 18(1), 94-106. https://doi.org/10.33557/mbia.v18i1.351.

Ejoh, N. O., Okpa, I. B., and Egbe, A. A. (2014). The impact of credit and liquidity risk management on the profitability of deposit money banks in Nigeria. International Journal of Economics, Commerce and Management, II(9), 1-15.

Fahmi, I. (2012). Analisis kinerja Keuangan (Bandung). Alfabeta.

Golitsis, P., and Fassas, A. (2019). Credit Risk Determinants: Evidence from the Bulgarian Banking System. Bulletin of Applied Economics, 6(1), 41-64.

Harsana, B, Setya; Suseno, dan Djoko, Y. R. (2018). Pengaruh Capital Adequacy,Liquidity Ratio,Credit Risk, Operational Efficiency,Debt to Equity Ratio dan Ukuran Perusahaan Terhadap Pertumbuhan Laba Bank. Jurnal Manajemen Sumber Daya Manusia, 12(1 Juni 2018), 1243-1251. http://link.springer.com/10.1007/s11664-01806850-8.

Herry. (2016). Analisis Kinerja Manajemen. PT. Grasindo.

Iftikhar, M. (2016). Impact of Credit Risk Management on Financial Performance of Commercial Banks of Pakistan. University of Haripur Journal of Management (UOHJM), 1(2), 110-125.

Irawati, N., Maksum, A., Sadalia, I., and Muda, I. (2019). Financial performance of indonesian's banking industry: the role of good corporate governance, capital adequacy ratio, non performing loan and size. International Journal of Scientific and Technology Research, 8(4), 22-26. 
Isanzu, S., and Juliana. (2017). The Impact of Credit Risk on the Financial Performance of Chinese Banks. Journal of International Business Research and Marketing, 2(3), 1417. https://doi.org/10.18775/jibrm.1849-8558.2015.23.3002.

Kalui, F. M. (2015). International Journal of Humanities Social Sciences and Education ( IJHSSE ) Effects of Credit Risk Management Procedures on Financial Performance among Microfinance Institutions ( MFIs) In Kenya: A Case of MFIs in Nairobi County. 2(3), 81-103.

Kauko, K. (2012). External deficits and non-performing loans in the recent financial crisis. Economics Letters, 115(2), 196-199. https://doi.org/10.1016/j.econlet.2011.12.018.

Kingu, S., Macha, D. S., and Gwahula, D. R. (2018). Impact of Non-Performing Loans on Bank's Profitability: Empirical Evidence from Commercial Banks in Tanzania. International Journal of Scientific Research and Management, 6(01), 71-78. https://doi.org/10.18535/ijsrm/v6i1.em11.

Lukitasari, Y. P., dan Kartika, A. (2015). Analisis Pengaruh Dana Pihak Ketiga, BOPO, CAR, LDR Dan NPL Terhadap Kinerja Keuangan Pada Sektor Perbankan Yang Terdaftar Di Bursa Efek Indonesia. Students' Journal of Accounting and Banking, $4(1), 28-39$.

Malla, B. K. (2018). Credit Portfolio Management in Nepalese Commercial Banks. Journal of Nepalese Business $\quad$ Studies, 10(1), 101-109. https://doi.org/10.3126/jnbs.v10i1.19138.

Matar, A., and Eneizan, B. (2018). Determinants of Financial Performance in the Industrial Firms: Evidence from Jordan. Asian Journal of Agricultural Extension, Economics \& Sociology, 22(1), 1-10. https://doi.org/10.9734/ajaees/2018/37476.

Melwani, R. (2019). Impact of Internal Financial Determinants on Financial Performance. Journal of Commerce \& Accounting Research, 8(3), 75-85.

Million, G., Matewos, K., and Sujata, S. (2015). The impact of credit risk on profitability performance of commercial banks in Ethiopia. African Journal of Business Management, 9(2), 59-66. https://doi.org/10.5897/ajbm2013.7171.

Mozib Lalon, R. (2015). Credit Risk Management (CRM) Practices in Commercial Banks of Bangladesh: "A Study on Basic Bank Ltd." International Journal of Economics, $\begin{array}{llll}\text { Finance } \quad \text { and } & \text { Management }\end{array}$ https://doi.org/10.11648/j.ijefm.20150302.12.

Nwude, E. C., and Okeke, C. (2018). Impact of Credit Risk Management on the Performance of Selected Nigerian Banks. International Journal of Economics and Financial Issues, 8(2), 287-297.

Peraturan Bank Indonesia Nomor 18/14/PBI/2016. (2016). Peraturan Bank Indonesia Nomor 18/14/PBI/2016 tentang Perubahan atas Peraturan Bank Indonesia Nomor 15/15/PBI/2013 tentang Giro Wajib Minimum Bank Umum dalam Rupiah dan Valuta Asing Bagi Bank Umum Konvensional. Bank Indonesia, 1, 1-5.

Pinasti, W. F., dan Mustikawati, R. I. (2018). Pengaruh Car, Bopo, Npl, Nim Dan Ldr Terhadap Profitabilitas Bank Umum Periode 2011-2015. Nominal, Barometer Riset Akuntansi Dan Manajemen, 7(1). https://doi.org/10.21831/nominal.v7i1.19365.

Poudel, R. P. S. (2012). Impact of Credit Risk Management on Financial Performance of Commercial Banks in Nepal. International Journal of Arts and Commerce, 1(5), 915.

Prasanjaya dan Ramantha. (2013). Analisis pengaruh rasio car, bopo, ldr dan ukuran 
perusahaan terhadap profitabilitas bank yang terdaftar di bei. E-Jurnal Akuntansi

Universitas Udayana, 1(ISSN: 2302-8556), 230-245.

Prasetyo, W. (2020). Analisis Faktor-faktor yang Mempengaruhi Profitabilitas Perbankan

Terbesar di Indonesia. Jurnal Akuntansi Dan Ekonomika, 10(1), 1-10. https://doi.org/10.37859/jae.v10i1.1872.

Putra, U. indra eka. (2015). Analisis Pengaruh Ukuran Perusahaan, Konsentrasi Pasar, Cost to Income Ratio , Leverage , dan Diversifikasi terhadap Volatilitas Laba. 4, 115.

Rajkumar, P., and Hanitha, V. (2015). the Impact of Credit Risk Management on Financial Performance a Study of State Commercial Banks in Sri Lanka. Proceeding of International Conference on Contemporary Management, 206-212.

Ruziqa, A. (2013). The impact of credit and liquidity risk on bank financial performance: The case of Indonesian conventional bank with total asset above 10 trillion rupiah. International Journal of Economic Policy in Emerging Economies, 6(2), 93-106. https://doi.org/10.1504/IJEPEE.2013.055791.

Saputra, I. M. H. E., \& Budiasih, I. G. A. N. (2016). Pengaruh Kecukupan Modal , Risiko Kredit ,. E-Jurnal Akuntansi Universitas Udayana, 3, 2363-2378.

Septiani, R., dan Lestari, P. V. (2016). Pengaruh Npl Dan Ldr Terhadap Profitabilitas Dengan Car Sebagai Variabel Mediasi Pada Pt Bpr Pasarraya Kuta. Journal of Chemical Information and Modeling, 05(01), 1689-1699.

Setiyawati, R. D., dan Hartini. (2019). Dampak credit risk management terhadap kinerja perusahaan perbankan yang terdaftar di Bursa Efek Indonesia. Jurnal Ekonomi Kiat, 30(1), 76-81.

Soegeng, F. X., Lusy, Inggawati, V. R., and Oetomo, H. W. (2018). Effect of Loan to Deposit Ratio (LDR), Non Performing Loan (NPL), Net Interet Margin (NIM) On Return on Assets (ROA) with ATM as Moderation Variables. Saudi Journal of Economics and Finance (SJEF), 2(5), 246-250.

Syamsiah, Abdul Rahman Mus, dan Asdar Djamereng. (2021). Pengaruh Capital Adequacy Ratio (CAR), Loan to Deposit Ratio (LDR), Biaya Operasional dan Pendapatan Operasional (BOPO) terhadap Return on Asset (ROA) pada Perbankan yang Terdaftar di Bursa Efek Indonesia. Tata Kelola, 8(1), 73-91. https://doi.org/10.52103/tatakelola.v8i1.482.

Teshome, E., Kenenisa, D., and Mohammed, sultan. (2014). Determinant of financial performance of commercial banks in Ethiopia: Special emphasis on private commercial. 12(1).

Undang Undang Nomor 10 Tahun 1998 tentang Perbankan. (1998). 63. http://www.komnasham.go.id/sites/default/files/dokumen/UU NO 39 TAHUN 1999 HAM_0.pdf.

Wanjohi, A., and Baimwera, mr. benard. (2016). an Analysis of the Effect of Credit Risk Management on Profitability of Commercial Banks in Kenya. International Journal of Finance and Accounting, 1(3), 38. https://doi.org/10.47604/ijfa.177.

Widati, Listyorini Wahyu, . (2016). Pengaruh Current Ratio, Debt to Equity Ratio, dan Return on Equity Untuk Memprediksi Kondisi Financial Distress. Jurnal Universitas Stikubank: Semarang., 1-16. 